\title{
Usability Testing Sesuai dengan ISO 9241-11 pada Sistem Informasi Program Pengalaman Lapangan Universitas Pendidikan Ganesha Ditinjau dari Pengguna Mahasiswa
}

\author{
Ni Luh Surya Wardani ${ }^{1}$, I Gede Mahendra Darmawiguna ${ }^{2}$, Nyoman Sugihartini ${ }^{3}$ \\ Program Studi Pendidikan Teknik Informatika \\ JurusanTeknik Informatika \\ Fakultas Teknik dan Kejuruan \\ Universitas Pendidikan Ganesha \\ Email : suryawardani09@gmail.com¹ ${ }^{1}$ mahendra.darmawiguna@ undiksha.ac.id ${ }^{2}$, sugihartini@ undiksha.ac.id ${ }^{3}$
}

\begin{abstract}
Abstrak---Sistem Informasi Program Pengalaman Lapangan (SI PPL) Undiksha adalah salah satu sistem informasi yang telah diterapkan untuk mendukung kegiatan PPL Real di Undiksha. Penelitian ini bertujuan untuk mengevaluasi SI PPL Undiksha serta dapat memberikan rekomendasi perbaikan atas sistem tersebut berdasarkan hasil evaluasi usability yang merujuk pada ISO 9241-11 yang ditinjau dari pengguna mahasiswa. Jenis penelitian ini adalah penelitian survei berbasis pengguna. Metode yang digunakan adalah metode usability testing dengan teknik wawancara untuk mendapatkan data awal, atribut efektifitas dan atribut efisiensi diukur menggunakan teknik Performance Measurementuntuk mengumpulkan data kuantitatif , serta atribut kepuasan diukur menggunakan teknik Restropective Think Alouduntuk mengumpulkan data kualitatif, dan kuesioner SUS. Hasil rekomendasi akan berpedoman pada 8 aturan emas untuk memperoleh desain interface yang efektif sehingga dapat mengoptimalkan perbaikan SI PPL Undiksha. Jumlah sampel yang ditentukan pada penelitian ini sebanyak 10 orang mahasiswa FTK di Undiksha angkatan 2015 yang berpotensi menggunakan SI PPL Undiksha.
\end{abstract}

Kata Kunci: Sistem Informasi PPL, Undiksha, Usability Testing

Abstract---Undiksha Field Experience Program Information System (SI PPL) is one of the information systems that has been implemented to support Real PPL activities at Undiksha. This study aims to evaluate the SI PPL Undiksha and can provide recommendations for improvements to the system based on the results of usability evaluation that refers to ISO 9241-11 which is reviewed by student users. This type of research is user-based survey research. The method used is the usability testing method with interview techniques to obtain initial data, attributes of effectiveness and efficiency attributes were measured using Performance Measurement techniques to collect quantitative data, and satisfaction attributes were measured using Think Aloud's Restropective technique to collect qualitative data, and SUS questionnaires. The recommendation results will be guided by 8 golden rules to obtain an effective interface design so as to optimize the improvement of the Undiksha SI $P P L$. The number of samples determined in this study were 10 FTK students at the 2015 Undiksha who had the potential to use the Undiksha SI PPL.

Keywords: Sistem Informasi PPL, Undiksha, Usability Testing

\section{PENDAHULUAN}

Universitas sebagai suatu organisasi tentunya membutuhkan sistem informasi dalam mengelola mahasiswa, sarana dan prasarana, dosen dan karyawan, keuangan, serta kegiatan lainnya yang berhubungan dengan penyelenggaraan kegiatan universitas. Sistem informasi merupakan kumpulan dari perangkat keras dan perangkat lunak komputer serta perangkat manusia yang akan mengolah data menggunakan perangkat keras dan perangkat lunak tersebut [1]. Universitas Pendidikan Ganesha (Undiksha) adalah salah satu universitas yang memiliki kegiatan Program Pengalaman Lapangan (PPL) yang harus diikuti oleh setiap mahasiswa keguruan termasuk mahasiswa jurusan PTI. Program Pengalaman Lapangan (PPL) merupakan suatu upaya untuk memperkenalkan calon guru pada dunia profesinya [2]. Untuk membantu kelancaran kegiatan PPL, seperti pengelolaan data serta penyampaian informasi kepada mahasiswa yang terkait dengan pelaksanaan kegiatan PPL, maka Undiksha merilis sebuah sistem yang disebut dengan Sistem Informasi Program Pengalaman Lapangan Undiksha (SI PPL Undiksha). 
Sistem Informasi Program Pengalaman Lapangan Undiksha (SI PPL Undiksha) dirilis pada tahun 2017 merupakan salah satu sistem informasi yang telah diterapkan di Undiksha untuk mendukung pelaksanaan kegiatan PPL Real di sekolah mitra. Terdapat empat pengguna SI PPL Undiksha yaitu pengguna Operator, pengguna Mahasiswa, pengguna Guru dan Pengguna Dosen. Melalui SI PPL Undiksha diharapkan dapat mendukung proses pelaksanaan PPL Real di sekolah mitra, dimulai dari pendaftaran, informasi aktivitas mahasiswa, pengumpulan berkas PPL Real, penilaian mahasiswa dan aktivitas lainnya. Sebelum sistem ini dirilis, mahasiswa yang berkepentingan harus datang langsung ke LP3M Undiksha untuk melakukan pendaftaran, pengumpulan berkas PPL Real dan aktivitas lainnya yang berhubungan dengan kegiatan PPL Real. Peneliti disini tertarik untuk meneliti SI PPL Undiksha yang ditinjau dari pengguna mahasiswa karena dilihat dari segi peranan dari sistem ini. SI PPL Undiksha yang ditinjau dari pengguna mahasiswa ini memiliki peranan yang sangat penting dalam hal administrasi mahasiswa baik itu pendaftaran PPL, pengumuman PPL, pengumpulan berkas PPL yang diperlukan, data pembimbing PPL, jurnal harian, upload file hingga informasi lengkap atau biodata mahasiswa dan lainnya yg berhubungan dengan PPL Real. SI PPL Undiksha yang ditinjau dari pengguna mahasiswa belum pernah dilakukan evaluasiyang dikaji dari segi usability-nya, Sehingga belum diketahui apakah SI PPL telah efektif, efisien, dan memberikan kepuasan bagi pengguna terhadap sistem tersebut.

Banyak terdapat website yang menyajikan beragam informasi, namun banyak juga yang tidak memenuhi tujuan dan bahkan mengecewakan pengguna yang mengaksesnya [3]. Pengujian usability juga menunjukan tingkat kemudahan suatu tampilan interface untuk dapat digunakan oleh pengguna layanan [4]

Usability testing memiliki beberapa teknik evaluasi yang berbeda. Diantara beberapa teknik tersebut terdapat teknik dengan mengukur performa keberhasilan dan kecepatan pengerjaan task (perintah) yaitu teknik Performance Measurement. Teknik ini dapat digunakan untuk memperoleh data kuantitatif tentang kinerja peserta tes ketika mereka melakukan tugas selama pengujian usability [5]. Teknik lain dalam metode usability testing yang dapat dikombinasikan dengan teknik tersebut adalah teknik Restrospective Think Aloud (RTA) yang digunakan untuk memperoleh data kualitatif, dimana data kualitatif tersebut berasal dari kata-kata verbal yang diutarakan oleh partisipan saat penelitian berlangsung dan diolah sebagai saran rekomendasi dengan acuan eight golden rules. Dalam golden rules of user interface design terbagi menjadi tiga hal yaitu menempatkan pengguna sebagai kontrol, memudahkan pengguna untuk mengingat, dan konsistensi antarmuka [6].
Pentingnya melakukan evaluasi melalui pengujian kebergunaan (usability testing) pada SI PPL Undiksha dibuktikan dengan adanya hasil penelitian yang dilakukan oleh Made Adhi Widya Sadnyana, dkkpada tahun 2017 yang berjudul "Evaluasi Usability Sistem Informasi Prakerin Pendidikan Teknik Informatika Di Universitas Pendidikan Ganesha Dengan Metode Usability Testing" bahwa setelah dilakukannya penelitian menggunakan usability testing diperoleh hasil Sistem Informasi Prakerin PTI masih belum efektif, karena masih ada error yang dilakukan responden mahasiswa atau dosen dalam melaksanakan tugas yang diberikan. Sistem Informasi Praekrin PTI dilihat dari hasil penghitungan waktu pelaksanaan tugas antara responden pemula atau mahir tidak terdapat perbedaan yang signifikan. Jadi Sistem Informasi Prakerin PTI bisa dikatakan efisien. Kemudian dalam tingkat kepuasan pengguna sistem Informasi Prakerin PTI masih kurang. Sedangkan berdasarkan penelitian yang dilakukan oleh Handiwidjojo dan Ernawati pada tahun 2016 yang berjudul "Pengukuran Tingkat Ketergunaan (Usability) Sistem Informasi Keuangan”. Setelah dilakukannya usability testing terhadap Sistem Informasi Keuangan diperoleh hasil bahwa Sistem memiliki tingkat ketergunaan (usability) baik (diatas rata-2 sekitar 72\%) sehingga dapat dikatakan sistem sudah cukup user friendly, diantara lima kriteria Neilson yaitu Learnability, Efficiency, dan Satisfaction mengindikasikan bahwa sistem mudah dipelajari, efisien dalam operasinya, dan pengguna cukup puas dalam menggunakan sistem, memorability dan Error berada dibawah rata-rata nilai keseluruhan. Berdasarkan hasil penelitian lain yang dilakukan oleh Zulkifli dan Sutomo pada tahun 2016 yang berjudul "Usability Testing Sistem Informasi Pendonor Darah"menunjukkan bahwa setelah dilakukannya pengukuran performa pengguna diperoleh waktu penyelesaian tugas yang cukup cepat, sebagian besar tugas diselesaikan dengan lengkap dan benar, menurutinforman aplikasi mudah untuk dipelajari dan memilikikecepatan yang lebih baik dibandingkan denganaplikasi yang digunakan sebelumnya. Sedangkan berdasarkan hasil penelitian yang dilakukan oleh Tri Rizqi Ariantoro pada tahun 2015 yang berjudul "Penerapan Metode Usability Pada Sistem Informasi Pelayanan Pelanggan (Studi Kasus : Website Pdam Tirta Musi Palembang)" menunjukkan bahwa website PDAM Tirta Musi Palembang belum memenuhi dari tingkat satisfaction (kepuasan), dimana perlu adanya penambahan menu informasi yaitu Informasi Telepon dan Alamat Lengkap Perusahaan, Informasi Unit Pelayanan, Site Map dan searching.

Berdasarkan hal diatas, maka penulis hendak melakukan penelitian yang berjudul "Usability Testing Sesuai Dengan ISO 9241-11Pada Sistem Informasi Program Pengalaman Lapangan Universitas Pendidikan Ganesha Ditinjau Dari Pengguna Mahasiswa" yang bertujuan untuk mengevaluasi SI PPL Undiksha serta dapat memberikan rekomendasi perbaikan 
atas sistem tersebut berdasarkan hasil evaluasi usability yang dilakukan.

\section{KAJIAN TEORI}

\section{A. Kajian Teori}

Pada penelitian mengenai evaluasi usability selain menjabarkan hasil evaluasi peneliti juga penting mencantumkan hasil rekomendasi perbaikan sistem. Berdasarkan penelitian yang berjudul "Evaluasi Web UJB Menggunakan Golden Rules Of User Interface Design Theo Mandel" bahwa kegagalan suatu sistem salah satunya karena kesalahan user interface yang terlalu rumit. User interface yang rumit justru membuat pengguna menjadi bingung untuk menggunakan sistem. Evaluasi user interface Web UJB mengunakan pendekatan golden rule of user interface design Theo Mandel. Dalam golden gules of user interface design" terbagi menjadi tiga hal yaitu menempatkan pengguna sebagai kontrol, memudahkan pengguna untuk mengingat, dan konsistensi antarmuka. Sehingga dengan evaluasi ini bisa dijadikan sebagai bahan pertimbangan dan referensi pada desain maupun kinerja dari Web UJB. Berdasarkan hasil evaluasi menyatakan bahwa secara umum desain interface dan kemudahan pengguna (usability) dari website Universitas Janabadara Yogyakarta sudah baik, namun masih ada beberapa hal yang perlu diperbaiki terutama dalam karakteristik menu dan submenu penguna.

Berdasarkan analisis literatur yang peneliti lakukan dengan beberapa kategori evaluasi usability yang ada menunjukkan bahwa metode yang cocok digunakan untuk mengevaluasi SI PPL adalah metode evaluasi usability testing sesuai standar ISO 9241-11. Untuk itu evaluasi yang akan dilakukan pada SI PPL mengadopsi metode usability testing dengan teknik Performance Measurement untuk mengumpulkan data kuantitatif dan teknik Restropective Think Aloud untuk mengumpulkan data kualitatif yang merupakan hasil verbalisasi pengguna setelah berinteraksi dengan sistem yang digunakan.

\section{B. Sistem Informasi Berbasis Web}

Sistem informasi merupakan kumpulan dari perangkat keras dan perangkat lunak komputer serta perangkat manusia yang akan mengolah data menggunakan perangkat keras dan perangkat lunak tersebut [1]. Sistem Informasi berbasis web merupakan sistem informasi yang menggunakan media website dalam mengelola seluruh aktivitas dan keterkaitan antar komponen [7].

\section{Sistem Informasi Program Pengalaman Lapangan (SI PPL)}

Program Pengalaman Lapangan (PPL) merupakan suatu kegiatan lapangan atau pengalaman lapangan yang dilaksanakan oleh mahasiswa yang mencakup latihan mengajar dan tugas kependidikan serat terbimbing dan terpadu untuk memenuhi syarat pembentukan profesi kependidikan [8].

Undiksha memiliki sebuah sistem untuk membantu kelancaran kegiatan PPL, seperti pengelolaan data serta penyampaian informasi kepada mahasiswa terkait dengan pelaksanaan kegiatan PPL di sekolah mitra yang disebut dengan Sistem Informasi Program Pengalaman Lapangan (SI PPL) Undiksha. Terdapat 4 pengguna pada SI PPL Undiksha ini yaitu, pengguna Operator, Mahasiswa, Dosen dan Guru.

\section{Eight Golden Rules}

Dalam membuat desain interface ada sebuah aturan Eight Golden Rules yang harus diperhatikan untuk mengoptimalkan desain yang akan dirancang, teori ini ditulis oleh Theo Mandel yang berjudul "Golden Rules of User Interface Design". Eight Golden Rules merupakan 8 aturan umum yang menjadi acuan dalam mengembangkan sebuah interface. Pada Eight Golden Rule desain antarmuka, mengeksplorasi cara mencegah kesalahan pengguna, dan menutup dengan bagian pada strategi kontroversial untuk mengintegrasikan otomatisasi dengan kontrol manusia [9]. Berikut adalah 8 aturan tersebut.

1. Berusaha untuk konsisten (Strive for consistency)

Aturan ini merupakan tindakan yang sifatnya konsisten. Perancangan sebuah desain perlu mempertimbangkan konsistensi meliputi ukuran font, gambar, logo, tata letak, menu, maupun warna.

2. Melayani kebutuhan berbagai pengguna (Cater to universal Usability)

Perancang desain sebaiknya mengetahui berbagai kebutuhan pengguna. Pengguna yang telah terbiasa berinterkasi dengan sebuah sistem akan berbeda dengan pengguna pemula dalam berinteraksi terhadap sistem. Perancangan harus dapat membedakan gaya akses berdasarkan kebutuhan dan kategorinya. Misalnya menyediakan tombol fungsi perintah-perintah tersembunyi untuk membuka menu atau fitur dalam interface untuk pengguna mahir dan menyediakan fitur normal berupa icon-icon yang mudah diakses oleh pengguna pemula.

3. Memberikan umpan balik yang informatif (Offer informative feedback)

Untuk setiap tindakan pengguna harus ada umpan balik sistem. Informative feedback tidak selalu berupa jawaban dari aplikasi ke user, namun dapat berupa perubahan antarmuka setiap user melakukan aksi, dengan demikian user paham bahwa aksinya sudah direspon oleh aplikasi.

4. Merancang dialog yang memberikan penutupan (keadaan akhir) (Design dialogs to yield closure)

Desain dialog antarmuka dirancang dengan menyampaikan bahwa proses yang dijalankan user sudah selesai, sehingga user paham bahwa tidak perlu menunggu apakah masih ada tahapan lain setelah menyelesaikan suatu proses. 


\section{Mencegah kesalahan (Prevent Errors)}

Desain sistem web yang ditawarkan perancang sebisa mungkin agar user tidak dapat membuat kesalahan dalam menjalan kan proses. Upaya agar user tidak merasa jenuh dalam mencoba menggunakan sistem, karena tidak bisa menemukan format / aksi yang tepat pada saat mencoba suatu fungsi. Biasanya terdapat petunjuk pengisian formulir sesuai format yang diterima oleh aplikasi, sehingga user dapat mengisi formulir dengan tepat pada percobaan pertama.

6. Memungkinkan pembalikan aksi yang mudah (Permit easy reversak of actions)

Kemudahan kepada user untuk kembali ketindakan sebelumnya apabila user melakukan kesalahan selama berinteraksi dengan antarmuka, sehingga akan mengurangi tingkat kecemasan user.

7. Mendukung pusat kendali internal (Support internal locus of control)

Aturan ini menjadikan user yang berpengalaman dapat mengendalikan sistem. Desain dapat membuat user dapat mngendalikan tanpa dikotrol oleh sistem karena sistem dirancang dengan menggunakan interaksi manusia dan komputer user-friendly. Seperti contohnya user biasanya ingin memiliki tampilan yang bisa diatur oleh user sendiri sesuai preferensi dari user. Hal ini dapat meningkatkan kepuasan user terhadap sistem.

8. Mengurangi beban ingatan jangka pendek (Reduce short-term memory load)

Setiap user memiliki memori jangka pendek yang terbatas. Keharusan mengingat beberapa hal secara bersamaan dapat membuat user frustasi. Mengunrangi beban ingatan jangka pendek dalam keterkaitan seluruh aturan dengan membuat tampilan interface mudah dan terlihat sederhana.

Rekomendasi perbaikan pada akhir penelitian ini berdasarkan Eight Golden Rule yang bertujuan mengahasilkan suatu wireframe perbaikan guna pengembangan selanjutnya.

\section{E. Kuesioner SUS (System Usability Scale)}

System Usability Scale (SUS) merupakan sebuah kuesioner yang dapat digunakan untuk mengukur usability dari sudut pandang pengguna. Kuesioner ini digunakan untuk mengukur nilai kepuasan pengguna terhadap SI PPL Undiksha. Kuesioner yang digunakan mengacu pada Standard Usability Questionnaires, yaitu SUS (System Usability System). SUS juga dikenal sebagai pengukur kepuasan pengguna yang "quick and dirty" artinya penggunaan kuesioner SUS sangat cepat dan data yang dihasilkan dapat dipercaya. Kuesioner ini terdiri dari sepuluh pernyataan berbeda dengan perbandingan antara pernyataan positif dan negatif adalah 5:5. Pernyataan nomor ganjil (1, 3, 5, 7, 9) merupakan pernyataan yang bernada positif, sedangkan pernyataan nomor genap $(2,4,6,8,10)$ merupakan pernyataan yang bernada negatif. Penelitian ini menggunakan lima buah skala Likert (sesuai dengan standar kuesoiner SUS) dengan keterangan jika, 1: Sangat tidak Setuju, 2: Tidak Setuju, 3: Netral, 4: Setuju, dan 5: Sangat Setuju.

Skor akhir SUS akan berada pada kisaran 0-100. Berdasarkan skor akhir SUS akan diketahui berapa tinggi tingkat usability dan acceptable desain system aplikasi yang dikembangkan. Penilaiannya berdasarkan tiga kategori yang berdasarkan skor nilai akhir dengan rentang nilai seperti pada table dibawah.

\begin{tabular}{|l|l|l|}
\multicolumn{3}{c}{ Tabel 1 Kategori Nilai SUS } \\
\hline No & Rentang Nilai & Status \\
\hline 1 & Skor akhir di (71-100) & Acceptable \\
\hline 2 & Skor akhir di (51-70.9) & Marginal \\
\hline 3 & Skor akhir di (0-50.9) & Not Acceptable \\
\hline
\end{tabular}

\section{METODOLOGI PENELITIAN}

\section{A. JenisPenelitian}

Jenis penelitian pada usability testing pada Sistem Informasi Program Pengalaman Lapangan (SI PPL) Undiksha yang ditinjau dari pengguna mahasiswa ini adalah penelitian survei berbasis pengguna, dengan metode deskriptif analitis. Penelitian ini menganalisis secara deskriptif mengenai evaluasi pengguna SI PPL ditinjau dari aspek usability yang didasari pada fakta yang terjadi.

\section{B. Variabel Penelitian}

Penelitian ini mengevaluasi Sistem Informasi Program Pengalaman Lapangan (SI PPL) yang diukur aspek usability sesuai ISO 9241-11 yang mencangkup atribut kualitas efektivitas, efisiensi, dan kepuasan.

\section{ProsedurPenelitian}

Prosedur dalam penelitian ini dapat dilihat pada gambar 1

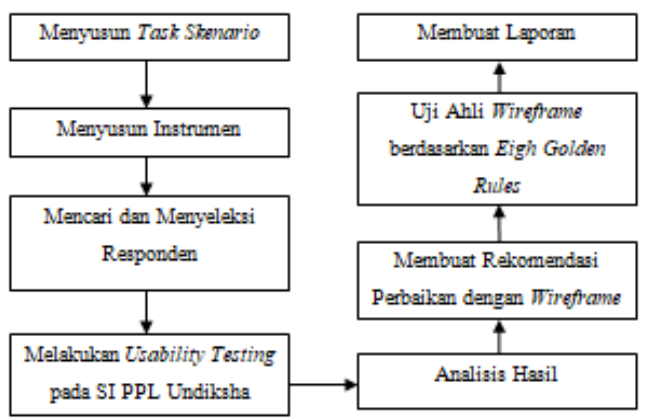

Gambar 1 Prosedur Penelitian

\section{Populasi Penelitian}

Populasi dalam penelitian ini adalah mahasiswa FTK angkatan 2015 di Undiksha yang telah memenuhi persyaratan untuk melakukan kegiatan PPL Real dan berpotensi menggunakan SI PPL Undiksha.

\section{E. Sampel Penelitian}

Teknik pengambilan sampel yang digunakan dalam penelitian ini adalah teknik Simple Random Samplingdimana 
pengambilan sampel dari populasi dilakukan secara acak tanpa mempertimbangkan strata yang ada dalam populasi itu. Jadi dalam penelitian ini cara pengambilan dari anggota populasi dilakukan secara acak tanpa memperhatikan strata (tingkatan) dalam anggota populasi tersebut.

Dalam banyak kasus, jumlah ideal pengguna untuk setiap putaran pengujian adalah tiga atau paling banyak empat. Hal tersebut dikarenakan jumlah pengguna yang sedikit lebih mudah dilakukan dengan hasil yang akurat dibanding pengguna yang banyak [10]. Pada penelitian ini peneliti menentukan sampel untuk melakukan usability testing pada SI PPL Undiksha adalah sebanyak 10 orang untuk mendapatkan hasil akhir yang baik. Responden dikelompokkan menjadi 2 kategori yakni responden mahir dan pemula penting dilakukan untuk mengetahui perbandingan waktu yang dibutuhkan responden dalam menyelesaikan tugas perkategorinya.

Tabel 2 Data Mahasiswa FTK Angkatan 2015 di Undiksha

\begin{tabular}{|c|l|c|}
\hline NO & \multicolumn{1}{|c|}{ JURUSAN } & JUMLAH \\
\hline 1 & Pendidikan Teknik Informatika & 79 \\
\hline 2 & Pendidikan Teknik Elektro & 23 \\
\hline 3 & Pendidikan Kesejahteraan Keluarga & 21 \\
\hline 4 & Pendidikan Teknik Mesin & 24 \\
\hline \multicolumn{2}{|c|}{ TOTAL } & $\mathbf{1 4 7}$ \\
\hline
\end{tabular}

Tabel 3 Perhitungan Jumlah Sampel Responden

\begin{tabular}{|c|c|c|c|c|c|c|c|}
\hline \multicolumn{8}{|c|}{ DATA MAHASISWA } \\
\hline $\begin{array}{l}\mathbf{N} \\
\mathbf{0}\end{array}$ & $\begin{array}{c}\text { Juru } \\
\text { san }\end{array}$ & $\begin{array}{l}\text { Jum } \\
\text { lah }\end{array}$ & \multicolumn{2}{|c|}{ Proporsi Sampel } & \multicolumn{2}{|c|}{$\begin{array}{c}\text { Perhitunga } \\
\text { n Sampel }\end{array}$} & $\begin{array}{c}\text { Sam } \\
\text { pel }\end{array}$ \\
\hline 1 & PTI & 79 & $\begin{array}{l}79 / 147 \\
\times 100 \% \\
\end{array}$ & $54 \%$ & $\begin{array}{c}54 \% x \\
10\end{array}$ & 5,4 & 5 \\
\hline 2 & PTE & 23 & $\begin{array}{l}23 / 147 \\
\times 100 \% \\
\end{array}$ & $16 \%$ & $\begin{array}{c}16 \% x \\
10\end{array}$ & 1,6 & 2 \\
\hline 3 & PKK & 21 & $\begin{array}{l}21 / 147 \\
\times 100 \% \\
\end{array}$ & $14 \%$ & $\begin{array}{c}14 \% \mathrm{x} \\
10\end{array}$ & 1,4 & 1 \\
\hline 4 & PTM & 24 & $\begin{array}{l}24 / 147 \\
\times 100 \% \\
\end{array}$ & $16 \%$ & $\begin{array}{c}16 \% x \\
10 \\
\end{array}$ & 1,6 & 2 \\
\hline \multicolumn{2}{|c|}{ TOTAL } & 147 & & $100 \%$ & & & 10 \\
\hline
\end{tabular}

\section{F. Teknik Pengumpulan Data}

Teknik pengumpulan data yang dilakukan dalam penelitian ini yaitu teknik wawancara, Performance Measurement, Restropective Think Aloud (RTA), kuesioner.

\section{a. Wawancara}

Dalam penelitian ini, wawancara dilakukan kepada pihak yang terkait dengan penelitian. Wawancara dilakukan untuk memperoleh kedalaman informasi yang dibutuhkan sekaligus memperoleh informasi masalah yang dihadapi pengguna saat menggunakan SI PPL Undiksha. Dalam melakukan wawancara, peneliti membawa instrumen sebagai pedoman untuk wawancara.

\section{b. Performance Measurement}

Dalam penelitian ini, teknik Performance Measurement digunakan untuk menghasilkan data kuantitatif mengenai performa responden saat melakukan penyelesaian task dalam sebuat tes untuk mengukur usability SI PPL Undiksha. Teknik ini dilakukan dengan cara merekam screen menjadi video menggunakan aplikasi camtasia ketika responden melakukan tes, dan memutar kembali data video yang dihasilkan, kemudian dihitung waktu pengerjaan responden menggunakan stopwatch dan disesuaikan dengan perhitungan waktu pada video. Teknik Performance Measurement menjadi bagian sangat penting dalam penelitian ini, karena dengan teknik ini dapat mengukur usability dari SI PPL Undiksha berdasarkan dua atribut dari tiga atribut kualitas dalam definisi usability, yaitu :

\section{Efektivitas}

Keefektifan SI PPL Undiksha akan dilihat dari keberhasilan responden dalam menyelesaikan task. Dari proses pengambilan data, apabila responden gagal menyelesaikan task karena salah masuk ke menu yang diinginkan atau menyerah maka responden tersebut dinilai melakukan error. Jika dalam proses penyelesaian task responden melakukan error maka halaman SI PPL Undiksha dapat dikatakan tidak efektif karena tidak mampu memberikan navigasi yang baik bagi penggunanya. Terdapat langkah dalam proses pengambilan data atribut efektivitas dengan teknik ini, yaitu:

a. Responden melakukan usability testing dalam sebuah tes task skenario yang telah disediakan untuk mengukur usability SI PPL Undiksha.

b. Proses pengambilan data responden dengan teknik Performance Measurement akan mengahasilkan data video yang menunjukkan aktivitas responden dalam pengerjaan setiap task skenario.

c. Dari video yang dihasilkan kemudian dilihat responden yang mengalami error disetiap task skenario atau berapa langkah halaman yang dibutuhkan atau dilalui oleh responden untuk menyelesaikan task.

d. Data pengerjaan task skenario kemudian dikumpulkan, serta diolah dan dianalisis.

e. Setelah diolah dan dianalisis data tiap responden, maka diketahui tingkat keefektifan SI PPL Undiksha berdasarkan ketepatan keberhasilan dan keakuratan responden dalam menyelesaikan setiap task skenario pada SI PPL Undiksha. 
2. Efisiensi

Keefisienan SI PPL Undiksha akan dilihat dari waktu pengerjaan yang dilakukan oleh responden dalam menyelesaikan tiap task skenario. Hasil akhir yang akan dianalisis adalah lama waktu yang digunakan responden dalam menyelesaikan setiap task dan dibandingkan dengan responden lain untuk memperoleh variabel efisiensi yang dihitung menggunakan rumus time base efisiency dan overall relative effisiency.

\section{c. Restropective Think Aloud (RTA)}

Teknik ini merupakan teknik yang digunakan untuk mengukur variabel kepuasan yang dikombinasikan dengan kuisioner SUS. Responden yang telah melakukan pengujian dengan sejumlah task, akan ditunjukan sebuah rekaman yang sudah dilakukan. Berdasarkan rekaman tersebut peneliti akan memberikan stimulus/rangsangan dengan pertanyaan terkait task, sehingga responden dapat memverbalisasikan masalah yang telah dihadapi saat menggunakan sistem. Pada teknik ini ada beberapa tahapan, yaitu:

a. Memutar kembali video yang didapat dari pengambilan data dengan teknik Performace Measurement, terlebih dahulu responden diberikan pengarahan untuk dapat menceritakan apa yang dipikirkan dalam mengerjakan task.

b. Responden memverbalisasikan pikirannya saat menjalankan task skenario.

c. Data verbal responden yang didapat dari hasil wawancara tersebut kemudian dikumpulkan.

d. Selanjutnya peneliti mendengar putaran ulang data rekaman setiap responden.

e. Peneliti menjadikan data tersebut menjadi data tertulis dan visual.

f. Kemudian data tertulis tersebut terbagi menjadi tiga bagian yaitu data kesimpulan think aload, data kepuasan dan data saran serta kritik responden.

g. Setelah diketahui hasil pengolahan data tersebut, maka akan diketahui kepuasan responden dalam menggunakan SI PPL Undiksha.

\section{d. Kuesioner}

Teknik pengumpulan data dalam penelitian ini dapat dilihat pada gambar 2 .

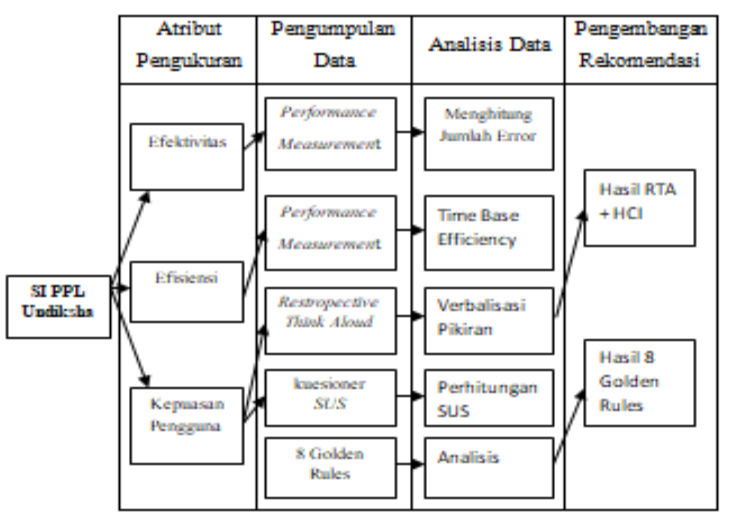

Gambar 2 Teknik Pengumpulan Data

G. Jenis Data

Adapun jenis data dalam penelitian ini yaitu.

1. Data kualitatif berupa hasil deskripsi maupun informasi dari keadaan atau fakta yang terjadi di lapangan mengenai perilaku pengguna SI PPL Undiksha yang diperoleh dari wawancara dan evaluasi usability testing menggunakan teknik Restropective Think Aload.

2. Data kuantitatif dalam penelitian ini berupa hasil evaluasi usability testing dengan menggunakan teknik Performance Measuremet dan kuesioner SUS.

H. Sumber Data

Sumber data dalam penelitian ini terdiri dari :

1. Data primer dalam penelitian ini adalah data yang didapat dari hasil survei terhadap responden mengenai evaluasi usability pada SI PPL Undiksha dengan menggunakan metode usability testing.

2. Data sekunder dalam penelitian ini adalah literatur, artikel, jurnal serta situs di internet yang berkenaan dalam penelitian ini.

I. InstrumenPenelitian

Pada penelitian ini instrumen penelitian yang digunakan yaitu dalam bentuk daftar task skenario, dan kuesioner SUS

a. Task Skenario

Pengukuran usability dilihat dari sukses atau tidaknya pengguna dalam melakukan setiap task, serta lamanya waktu pengguna dalam menyelesaikan setiap task. Berikut adalah task skenario yang digunakan dalam penelitian ini, antara lain:

Tabel 4 Fungsi dan Task Skenario Evaluasi Usability pada Sistem Informasi PPL

\begin{tabular}{|c|l|}
\hline NO & \multicolumn{1}{|c|}{ INSTRUKSI } \\
\hline 1 & $\begin{array}{l}\text { Silahkan masuk (Login) ke SI PPL Undiksha } \\
\text { menggunakan username dan password yang sesuai. }\end{array}$ \\
\hline 2 & Silahkan masuk ke halaman Pendaftaran PPL Real. \\
\hline 3 & $\begin{array}{l}\text { Silahkan cek data diri dan lihat pengumuman PPL } \\
\text { dengan mengkik pada tombol +Lihat Pengumuman, } \\
\text { lalu pilih salah satu untuk melihat secara detail atau }\end{array}$ \\
\hline
\end{tabular}




\begin{tabular}{|c|l|}
\hline NO & \multicolumn{1}{|c|}{ INSTRUKSI } \\
\hline & untuk mengunduh berkas PPL. \\
\hline 4 & Silahkan masuk ke halaman Informasi Pembimbing. \\
\hline 5 & Silahkan lakukan tambah/edit guru pembimbing. \\
\hline 6 & Silahkan lakukan tambah/edit kepsek pembimbing. \\
\hline 7 & $\begin{array}{l}\text { Silahkan cetak bukti bahwa telah berhasil } \\
\text { melakukan pendaftaran PPL Real dengan mengklik } \\
\text { pada menu Cetak Bukti PPL Real. }\end{array}$ \\
\hline 8 & Silahkan masuk ke halaman Jurnal Harian. \\
\hline 9 & $\begin{array}{l}\text { Silahkan isi jurnal kegiatan dengan mengklik } \\
\text { tombol Tambah Data. }\end{array}$ \\
\hline 10 & Silahkan masuk ke halaman Upload File. \\
\hline 11 & Silahkan upload file/berkas PPL Real. \\
\hline 12 & Silahkan keluar (Logout) dari SI PPL Undiksha. \\
\hline
\end{tabular}

\section{b. Kuesioner SUS}

Instumen kuesioner dalam penelitian ini yaitu menggunakan kuesioner yang mengacu pada Standard Usability Questonares yaitu SUS. Kuesioner SUS digunakan untuk mengukur nilai kepuasan. Faktor kepuasan mengacu pada persepsi, perasaan, dan pendapat responden dari SI PPL Undiksha. Hal ini diukur menggunakan kuesioner SUS yang nantinya akan diolah datanya. Pengambilan data menggunakan kuesioner SUS dilakuakan setelah menyelesaikan semua task skenario yang diberikan untuk pengujian kebergunaan pada SI PPL Undiksha. SUS juga dikenal sebagai pengukur kepuasan pengguna yang quick and dirty, artinya penggunaan kuesioner SUS sangat cepat dan data yang dihasilkan dapat dipercaya.

\section{J. Analisis Data}

\section{a. Data Kuantitatif}

Pengumpulan data kuantitatif dilakukan dengan evaluasi usability testing menggunakan teknik Performance Measurement dan penyebaran kuesioner (SUS) kepada responden.

\section{Teknik Performance Measuement}

Untuk melihat kefektifan halaman SI PPL Undiksha akan dilihat dari jumlah task yang berhasil diselesaikan responden. Penyelesaian dihitung dengan menetapkan angka biner ' 1 ' jika partisipan berhasil dan ' 0 ' jika partisipan gagal. Rumus yang digunakan adalah sebagai berikut:

$$
\text { Ef ektifitus }=\frac{\text { jumlah tugas yang berhasil diselesaikan }}{\text { Jumlah total tugas }} x 100 \%
$$

Pada rumus diatas dijabarkan untuk memperoleh hasil efektifitas, banyaknya tugas yang diselesaikan dan berhasil dibagi banyaknya total tugas yang diberikan yang hasilnya dikalikan $100 \%$. Rata-rata penyelesaian tugas minimum pada pengujian usability adalah $78 \%$, namun bila hasil dibawah 49\% menempatkan pada kuartil bawah (Sauro, 2011).
Sedangkan untuk mengukur keefektifan SI PPL Undiksha dapat diukur dalam waktu tugas, yaitu waktu dalam hitungan menit/detik yang dibutuhkan untuk menyelesaikan tugas dengan sukses. Rumus yang digunakan untuk menghitung keefisienan suatu produk atau layanan adalah sebagai berikut:

a. Time Base Efficiency

Waktu yang diperoleh diukur dengan mengurangkan waktu selesai dengan waktu mulai, kemudian dihitung menggunakan persamaan berikut.

$$
\text { Efisiensi efektif keseluruhan }=\frac{\sum_{j=1}^{g} \sum_{i=1}^{N} \frac{n_{i j}}{t_{i j}}}{N R}
$$

Keterangan :

$\mathrm{N}=$ Jumlah total tugas (gol)

$\mathrm{R}=$ Jumlah pengguna

nij $=$ Hasil tugas $\mathrm{i}$ oleh pengguna $\mathrm{j}$; jika pengguna berhasil menyelesaikan tugas, maka $\mathrm{Nij}=1$, jika tidak, maka $\mathrm{Nij}=0$

tij = Waktu yang dihabiskan oleh pengguna $\mathrm{j}$ untuk menyelesaikan tugas i. Jika tugas tidak berhasil diselesaikan, maka waktu diukur hingga saat pengguna berhenti dari tugas

2. Kuesioner SUS (System Usability Scale)

Tingkat kepuasan dapat diukur dengan mengisi kuisioner System Usability Scale (SUS). Nilai yang dihasilkan akan menentukan kualitas suatu produk, kualitas yang baik apabila skor SUS yang diperoleh $>=\mathbf{7 0}$ [11]. Tabel rentang nilai dapat dicermati pada tabel 5. Adapun rumus yang digunakan untuk menghitung adalah sebagai berikut:

$$
\text { Nilai rata }- \text { rata }=\sum_{i=1}^{n} \frac{x_{i}}{N}
$$

Keterangan $: X i=$ nilai score responden dan $\mathrm{N}=$ jumlah responden.

b. Data Kualitatif

Data kualitatif diperoleh dari teknik Restropective Think Aload berupa data verbal responden yang didapat dari hasil wawancara mengenai apa saja yang dipikirkan responden selama menjalankan tahapan-tahapan untuk menyelesaian task skenario dengan menggunakan video. Untuk membuat data tersebut menjadi data yang dapat disajikan secara tertulis dan visual, penulis mendengarkan ulang rekaman dari setiap responden dan kemudian membuatnya menjadi data secara tertulis dan visual. Data hasil rekaman tersebut disajikan kedalam tiga data utama yaitu data kesimpulan think aload, data kepuasaan, data kritik serta saran dari responden evaluasi usability pada SI PPL Undiksha.

\section{K. Dasar Pengembangan Rekomendasi}

Acuan yang peneliti gunakan untuk memberikan rekomendasi perbaikan SI PPL Undiksha diperoleh dari:

1. Hasil verbalisasi responden menggunakan teknik restropective think aload berupa kritik dan saran ketika berinteraksi dengan SI PPL Undiksha. 
2. Setelah diketahui hasil perbaikan SI PPL Undiksha, maka diimplementasikan kedalam bentuk rancangan/wireframe. Pengembangan perbaikan menggunakan software MockUp yang mengacu pada aturan Eight Golden Rules. Adapun bagian-bagian dari aturan pada SI PPL Undiksha adalah sebagai berikut:

a. Berusaha untuk konsisten (Strive for consistency) Aturan ini merupakan tindakan yang sifatnya konsisten. Perancangan sebuah desain perlu mempertimbangkan konsistensi meliputi ukuran font, gambar, logo, tata letak, menu, maupun warna.

b. Melayani kebutuhan berbagai pengguna (Cater to universal usability) misalnya pemula/mahir dengan menyediakan fitur tertentu yang mendukung pengguna mahir untuk mengurangi jumlah interaksi dibandingkan pengguna pemula.

- Pada gambar 3.2 untuk melihat melihat data diri pengguna harus mengklik menu "Pendaftaran PPL Real", sehingga pengguna awal yang menggunakan sistem melihat menu "Pendaftaran PPL Real" dipersepsikan menu tersebut untuk melakukan pendaftaran bukan untuk melihat data pribadi.

- Pada gambar 3.3 pilihan Lihat Pengumuman tidak berada dilist menu pada bagian kiri melainkan bergabung dengan menu "Pendaftaran PPL Real.

3. Memberikan umpan balik yang informatif (Offer informative feedback). Untuk setiap tindakan pengguna harus ada umpan balik sistem. Informative feedback tidak selalu berupa jawaban dari aplikasi ke user, namun dapat berupa perubahan antarmuka setiap user melakukan aksi, dengan demikian user paham bahwa aksinya sudah direspon oleh aplikasi.

4. Merancang dialog yang memberikan penutupan (keadaan akhir) (Design dialogs to yield closure). Desain dialog antarmuka dirancang dengan menyampaikan bahwa proses yang dijalankan user sudah selesai, sehingga user paham bahwa tidak perlu menunggu apakah masih ada tahapan lain setelah menyelesaikan suatu proses.

5. Mencegah kesalahan (Prevent errors). Desain sistem web yang ditawarkan perancang sebisa mungkin agar user tidak dapat membuat kesalahan dalam menjalankan proses. Upaya agar user tidak merasa jenuh dalam mencoba menggunakan sistem, karena tidak bisa menemukan format/aksi yang tepat pada saat mencoba suatu fungsi. Biasanya terdapat petunjuk pengisian formulir sesuai format yang diterima oleh aplikasi, sehingga user dapat mengisi formulir dengan tepat pada percobaan pertama.

6. Memungkinkan pembalikan aksi yang mudah (Permit easy reversak of actions). Kemudahan kepada user untuk kembali ketindakan sebelumnya apabila user melakukan kesalahan selama berinteraksi dengan antarmuka, sehingga akan mengurangi tingkat kecemasan user.

7. Mendukung pusat kendali internal (Support internal locus of control). Aturan ini menjadikan user yang berpengalaman dapat mengendalikan sistem. Desain dapat membuat user dapat mngendalikan tanpa dikotrol oleh sistem karena sistem dirancang dengan menggunakan interaksi manusia dan komputer userfriendly. Seperti contohnya user biasanya ingin memiliki tampilan yang bisa diatur oleh user sendiri sesuai preferensi dari user. Hal ini dapat meningkatkan kepuasan user terhadap sistem.

8. Mengurangi beban ingatan jangka pendek (Reduce short-term memory load). Setiap user memiliki memori jangka pendek yang terbatas. Keharusan mengingat beberapa hal secara bersamaan dapat membuat user frustasi. Mengunrangi beban ingatan jangka pendek dalam keterkaitan seluruh aturan dengan membuat tampilan interface mudah dan terlihat sederhana.

\section{HASIL DAN PEMBAHASAN}

A. Hasil Performance Measurement

Hasil usability testing dengan teknik Performance Measurement diperoleh dari data kecepatan dengan melihat waktu penyelesaian disetiap task skenario terhadap 10 responden penelitian. Data hasil teknik Performance Measurement 
Tabel 5 Waktu Pengerjaan Tugas Responden Mahasiswa

\begin{tabular}{|c|c|c|c|c|c|c|c|c|c|c|c|c|}
\hline \multirow{2}{*}{ Kode } & \multicolumn{12}{|c|}{ Waktu Pengerjaan Setiap Task Skenario (detik) } \\
\hline & $\mathbf{T 1}$ & $\mathbf{T} 2$ & T3 & T4 & $\mathbf{T 5}$ & T6 & T7 & TS & T9 & T10 & T11 & T12 \\
\hline RPI & 36 & 3 & 8 & 4 & 5 & 6 & 13 & 6 & 21 & 5 & 16 & 8 \\
\hline RP2 & 37 & 3 & 2 & 5 & 9 & 10 & 13 & 4 & 24 & 5 & 13 & 5 \\
\hline RP3 & 33 & 1 & 3 & 10 & 9 & 18 & 7 & 6 & 23 & 6 & 12 & 5 \\
\hline RP4 & 65 & Error & 14 & 7 & Error & 13 & 2 & 6 & 49 & Error & Error & 8 \\
\hline RP5 & 29 & 3 & 3 & 4 & 15 & 19 & 5 & 6 & 59 & 2 & 15 & 4 \\
\hline RMI & 26 & 6 & 9 & 2 & 6 & 8 & 5 & 3 & 54 & 1 & 18 & 1 \\
\hline RM2 & 37 & 6 & 33 & 3 & 10 & 14 & 3 & 3 & 40 & 3 & 19 & 3 \\
\hline RM3 & 28 & 4 & 4 & 4 & 28 & 12 & 2 & 3 & 23 & 3 & 14 & 5 \\
\hline RM4 & 65 & 2 & 5 & 1 & 12 & 9 & 2 & 2 & 41 & 2 & 12 & 11 \\
\hline RM5 & 22 & 9 & 4 & 3 & 7 & 8 & 2 & 3 & 19 & 3 & 22 & 2 \\
\hline
\end{tabular}

Merupakan hasil waktu dalam pengerjaan masing-masing tugas paa setiap responden. Waktu pengerjaan setiap tugas dihitung dengan satuan waktu detik. Jika error menunjukkan bahwa responden tidak berhasil menyelesaikan tugas.

B. Hasil Restropective Think Aloud (RTA)

Hasil usability testing dengan teknik Restropektive Think Aloud (RTA)

Tabel 6 Data Think Aload Pengguna SI PPL

\begin{tabular}{|c|c|c|c|}
\hline No & $\begin{array}{c}\text { Kode } \\
\text { Responden }\end{array}$ & $\begin{array}{l}\text { Masalah yang } \\
\text { didapat dari } \\
\text { kesimpulan data } \\
\text { Think Aload }\end{array}$ & $\begin{array}{l}\text { Kritik dan } \\
\text { Saran yang } \\
\text { diberikan }\end{array}$ \\
\hline 1 & RP1 & $\begin{array}{lr}\text { Masih } & \text { kebingungan } \\
\text { dalam } & \text { melihat } \\
\text { pengumuman }\end{array}$ & $\begin{array}{l}\text { Menu lebih } \\
\text { disederhanak } \\
\text { an }\end{array}$ \\
\hline 2 & RP2 & $\begin{array}{l}\text { Masih kebingungan } \\
\text { saat mencari fitur lihat } \\
\text { pengumuman karena } \\
\text { tombol terlalu kecil }\end{array}$ & \begin{tabular}{lr}
\multicolumn{2}{l}{ Kumpulkan } \\
saja & fitur \\
pada & bilah \\
kiri & dengan \\
menu & yang \\
lain &
\end{tabular} \\
\hline 3 & RP3 & $\begin{array}{l}\text { Kebingungan mencari } \\
\text { fitur lihat } \\
\text { pengumuman karena } \\
\text { tombol terlalu kecil } \\
\text { dan pada menu upload } \\
\text { file tidak terdapat fitur } \\
\text { hapus file }\end{array}$ & $\begin{array}{l}\text { Perbesar } \\
\text { tombol lihat } \\
\text { pengumuma } \\
\mathrm{n} \text { dan } \\
\text { tambahkan } \\
\text { fitur hapus } \\
\text { file pada } \\
\text { menu upload } \\
\text { file }\end{array}$ \\
\hline 4 & RP4 & $\begin{array}{l}\text { Masih kebingungan } \\
\text { saat mengakses menu } \\
\text { upload file }\end{array}$ & $\begin{array}{l}\text { Lebih } \\
\text { diperjelas } \\
\text { tampilannya }\end{array}$ \\
\hline
\end{tabular}

\begin{tabular}{|c|c|c|c|}
\hline No & $\begin{array}{c}\text { Kode } \\
\text { Responden }\end{array}$ & $\begin{array}{l}\text { Masalah yang } \\
\text { didapat dari } \\
\text { kesimpulan data } \\
\text { Think Aload }\end{array}$ & $\begin{array}{l}\text { Kritik dan } \\
\text { Saran yang } \\
\text { diberikan }\end{array}$ \\
\hline 5 & RP5 & $\begin{array}{l}\text { Tidak dapat } \\
\text { menghapus file yg } \\
\text { salah karena tidak ada } \\
\text { pilihan hapus file }\end{array}$ & $\begin{array}{l}\text { Tambahkan } \\
\text { fitur hapus } \\
\text { file }\end{array}$ \\
\hline 6 & RM1 & $\begin{array}{lrr}\text { Terlalu lama } & \text { saat } \\
\text { mencari fitur lihat } \\
\text { pengumuman }\end{array}$ & $\begin{array}{l}\text { Gabungkan } \\
\text { saja di } \\
\text { bagian menu } \\
\text { yang lain }\end{array}$ \\
\hline 7 & RM2 & $\begin{array}{l}\text { Kebingungan mencari } \\
\text { tombol lihat } \\
\text { pengumuman dan } \\
\text { tidak bisa melakukan } \\
\text { hapus file }\end{array}$ & $\begin{array}{l}\text { Buatkan } \\
\text { menu lain } \\
\text { untuk lihat } \\
\text { pengumuma } \\
\mathrm{n} \text { dan } \\
\text { tambahkan } \\
\text { tombol } \\
\text { hapus file }\end{array}$ \\
\hline 8 & RM3 & $\begin{array}{l}\text { Kebingungan karena } \\
\text { beberapa menu yang } \\
\text { penempatannya } \\
\text { kurang tepat, seperti } \\
\text { lihat pengumuman } \\
\text { dan kurangnya fitur } \\
\text { hapus file pada menu } \\
\text { upload file }\end{array}$ & $\begin{array}{l}\text { Letakkan } \\
\text { tombol lihat } \\
\text { pengumuma } \\
\text { n pada bilah } \\
\text { kiri } \\
\text { kumpulkan } \\
\text { dengan menu } \\
\text { yang lain }\end{array}$ \\
\hline 9 & RM4 & $\begin{array}{lr}\text { Kesusahan } & \text { saat } \\
\text { mencari tombol lihat } \\
\text { pengumuman } & \text { karena } \\
\text { fitur } & \text { lihat } \\
\text { pengumuman } & \text { terlalu } \\
\text { kecil } & \end{array}$ & $\begin{array}{l}\text { Perbesar } \\
\text { tombol lihat } \\
\text { pengumuma } \\
\text { n }\end{array}$ \\
\hline
\end{tabular}


P-ISSN 2252-9063

Kumpulan Artikel Mahasiswa Pendidikan Teknik Informatika

(KARMAPATI)

KดRMดPดTI

\begin{tabular}{|l|l|l|l|}
\hline No & $\begin{array}{c}\text { Kode } \\
\text { Responden }\end{array}$ & $\begin{array}{c}\text { Masalah yang } \\
\text { didapat dari } \\
\text { kesimpulan data } \\
\text { Think Aload }\end{array}$ & $\begin{array}{c}\text { Kritik dan } \\
\text { Saran yang } \\
\text { diberikan }\end{array}$ \\
\hline 10 & RM5 & $\begin{array}{l}\text { Tidak bisa menghapus } \\
\text { file yang salah karena } \\
\text { tidak ada tombol } \\
\text { hapus file pada menu } \\
\text { upload file }\end{array}$ & $\begin{array}{l}\text { Tambahkan } \\
\text { fitur hapus } \\
\text { data }\end{array}$ \\
\hline
\end{tabular}

Berdasarkan tabel tersebut dapat disimpulkan bahwa terdapat beberapa masalah atau kesulitan yang dialami responden saat menggunakan Sistem Informasi PPL Undiksha. Kesimpulan masalah atau kesulitan responden tersebut terangkum pada tabel berikut ini.

Tabel 7 Kesimpulan Masalah/Kesulitan yang dialami Responden

\begin{tabular}{|c|l|l|l|}
\hline No & Kode Responden & \multicolumn{1}{|c|}{ Fitur } & $\begin{array}{l}\text { Kesulitan yang } \\
\text { dialami }\end{array}$ \\
\hline 1 & $\begin{array}{l}\text { RP1, RP2, RP3, } \\
\text { RM1, RM2, RM3, } \\
\text { RM4 }\end{array}$ & $\begin{array}{l}\text { Lihat } \\
\text { Pengumuman }\end{array}$ & $\begin{array}{l}\text { Pengguna } \\
\text { merasa } \\
\text { kebingungan } \\
\text { karena tombol } \\
\text { lihat } \\
\text { pengumuman } \\
\text { terlalu kecil }\end{array}$ \\
\hline 2 & $\begin{array}{l}\text { RP3, RP4, RP5, } \\
\text { RM2, RM3, RM5 }\end{array}$ & Upload File & $\begin{array}{l}\text { Pengguna tidak } \\
\text { dapat } \\
\text { melakukan } \\
\text { hapus file }\end{array}$ \\
\hline
\end{tabular}

Tabel diatas menunjukkan masalah atau kesulitan yang dialami responden saat menggunakan SI PPL. Selain kesulitan dan masalah yang dialami, responden juga memberikan kritik dan saran guna membangun SI PPL menjadi lebih baik. Berikut adalah kesimpulan dari saran yang diberikan oleh responden.

Tabel 8 Kesimpulan Saran Responden

\begin{tabular}{|l|l|l|}
\hline No & Kode Responden & $\begin{array}{c}\text { Kritik dan Saran yang } \\
\text { diberikan }\end{array}$ \\
\hline 1 & $\begin{array}{l}\text { RP1, RP2, RP3, } \\
\text { RM1, RM2, RM3, } \\
\text { RM4 }\end{array}$ & $-\begin{array}{l}\text { Perbesar tampilan } \\
\text { tombol lihat } \\
\end{array}$ \\
& & $\begin{array}{l}\text { pengumuman } \\
\text { Buatkan menu lihat } \\
\text { pengumuman dibilah } \\
\text { kiri sejajar dengan menu } \\
\text { yang lain }\end{array}$ \\
\hline
\end{tabular}

Volume 8, Nomor 2, Tahun 2019

\begin{tabular}{|c|c|c|}
\hline No & Kode Responden & $\begin{array}{c}\text { Kritik dan Saran yang } \\
\text { diberikan }\end{array}$ \\
\hline 3 & $\begin{array}{l}\text { RP3, RP4, RP5, } \\
\text { RM2, RM3, RM5 }\end{array}$ & $\begin{array}{l}\text { - } \quad \text { Tambahkan fitur hapus } \\
\text { file pada menu upload } \\
\text { file }\end{array}$ \\
\hline
\end{tabular}

Tabel diatas menunjukkan kesimpulan dan saran responden berikan setelah menggunakan SI PPL. Proses usability testing dengan teknik RTA juga diperoleh hasil data berupa rekapitulasi kepuasan pengguna.

\section{Hasil Efektivitas}

Analisis efektivitas diukur dengan melihat terjadinya error saat responden menyelesaikan tugas. Berikut dijabarkan analisis beserta hasil efektivitas SI PPL dari pengguna.

Tabel 9 Data Kesalahan (Error) Pengguna Responden

\begin{tabular}{|r|r|r|r|}
\hline Tugas & \multicolumn{1}{|c|}{$\begin{array}{c}\text { Jumlah } \\
\text { Responden }\end{array}$} & $\begin{array}{c}\text { Jumlah } \\
\text { Error }\end{array}$ & $\begin{array}{c}\text { Presentase } \\
\text { Jumlah Error } \\
\text { (\%) }\end{array}$ \\
\hline 1 & 10 & 0 & $0.00 \%$ \\
\hline 2 & 10 & 1 & $10.00 \%$ \\
\hline 3 & 10 & 0 & $0.00 \%$ \\
\hline 4 & 10 & 0 & $0.00 \%$ \\
\hline 5 & 10 & 1 & $10.00 \%$ \\
\hline 6 & 10 & 0 & $0.00 \%$ \\
\hline 7 & 10 & 0 & $0.00 \%$ \\
\hline 8 & 10 & 0 & $0.00 \%$ \\
\hline 9 & 10 & 0 & $0.00 \%$ \\
\hline 10 & 10 & 1 & $10.00 \%$ \\
\hline 11 & 10 & 1 & $10.00 \%$ \\
\hline 12 & 10 & 0 & $0.00 \%$ \\
\hline
\end{tabular}

Berdasarkan data error responden yang ditampilkan yang ditampilkan pada Tabel 9 menunjukkan bahwa ada responden yang melakukan error atau gagal menyelesaikan tugas. Presentasi kesalahan error yang terjadi oleh responden pada tugas 2, 5, 10 dan 11. Error yang terjadi oleh responden dapt diketahui melalui video Performance Measurement untuk masing-masing responden yang melakukan kesalahan atau error. Jadi berdasarkan rata-rata yang diperoleh dari hasil efektifitas tiap responden menunjukkan keakuratan dan kelengkapan responden untuk mencapai tujuan dalam menggunakan Sistem Informasi PPL Undiksha adalah 96,3\%. Rata-rata minimum penyelesaian tugas pada pengujian usability adalah $78 \%$ sesuai dengan penjelasan yang telah tercantum pada bab dua, sehingga hasil rata-rata keefektifitasan Sistem Informasi PPL yang menghasilkan 96,3\% tersebut termasuk dalam kategori efektif. Pada tabel 10 
P-ISSN 2252-9063

Kumpulan Artikel Mahasiswa Pendidikan Teknik Informatika

(KARMAPATI)

KARMAPAT

berikut perincian pennyebab kesalahan yang dilakukan oleh responden.

Tabel 10 Data Penyebab Kesalahan (Error) Responden

\begin{tabular}{|l|l|l|}
\hline \multicolumn{1}{|c|}{ Tugas } & \multicolumn{1}{|c|}{$\begin{array}{c}\text { Kode } \\
\text { Responden }\end{array}$} & \multicolumn{1}{|c|}{\begin{tabular}{c}
\multicolumn{1}{c|}{ Penyebab Kesalahan } \\
(Error)
\end{tabular}} \\
\hline Tugas 2 & RP4 & $\begin{array}{l}\text { Responden langsung pindah } \\
\text { ke tugas selanjutnya tanpa } \\
\text { menyelesaikan tgs 2 terlebih } \\
\text { dahulu }\end{array}$ \\
\hline Tugas 5 & RP4 & $\begin{array}{l}\text { Salah saat melakukan input } \\
\text { data }\end{array}$ \\
\hline Tugas 10 & RP4 & $\begin{array}{l}\text { Responden tidak } \\
\text { mengerjakan tugas }\end{array}$ \\
\hline Tugas 11 & RP4 & $\begin{array}{l}\text { Responden tidak } \\
\text { mengerjakan tugas }\end{array}$ \\
\hline
\end{tabular}

Dari beberapa faktor penyebab kesalahan atau error yang dilakukan responden pada Tabel 10 diatas diketahui bahwa responden mengalami kesalahan dalam mengerjakan tugas 2 , 5, 10 dan 11. Berdasarkan acuan pada bab 3 jika nilai pada variable efektifitas diatas $78 \%$ maka dapat disimpulkan bahwa SI PPL memiliki kualitas efektifitas yang tergolong sangat baik. Adanya kegagalan pengerjaan tugas disebabkan oleh faktor sebagaimana tersaji pada tabel 10 .

\section{Hasil Efisiensi}

Untuk mengukur efisiensi pengerjaan tugas pada Sistem Informasi PPL Undiksha dilakukan dengan membandingkan waktu pengerjaan responden pemula dengan responden mahir pada hasil pengukuran usability Sistem Informasi PPL Undiksha menggunakan Mann Whitney U-test.

Tabel 7 berikut merupakan output rank dari hasil pengujian statistic dengan Mann Whitney U-test pada waktu pengerjaan tugas responden dosen kelompok pemula (1) dengan kelompok mahir (2).

Tabel 11 Output Rank Pengolahan Data Responden Mahasiswa

Ranks

\begin{tabular}{|ll|r|r|r|}
\hline & Kelompok & N & Mean Rank & Sum of Ranks \\
\hline Tugas1 & Pemula & 5 & 6,40 & 32,00 \\
& Mahir & 5 & 4,60 & 23,00 \\
& Total & 10 & & \\
\hline Tugas2 & Pemula & 5 & 4,20 & 21,00 \\
& Mahir & 5 & 6,80 & 34,00
\end{tabular}

Volume 8, Nomor 2, Tahun 2019 Ranks

\begin{tabular}{|c|c|c|c|c|}
\hline & Kelompok & $\mathrm{N}$ & Mean Rank & Sum of Ranks \\
\hline & Total & 10 & & \\
\hline \multirow[t]{3}{*}{ Tugas3 } & Pemula & 5 & 4,40 & 22,00 \\
\hline & Mahir & 5 & 6,60 & 33,00 \\
\hline & Total & 10 & & \\
\hline \multirow[t]{3}{*}{ Tugas4 } & Pemula & 5 & 7,80 & 39,00 \\
\hline & Mahir & 5 & 3,20 & 16,00 \\
\hline & Total & 10 & & \\
\hline \multirow[t]{3}{*}{ Tugas5 } & Pemula & 5 & 5,40 & 27,00 \\
\hline & Mahir & 5 & 5,60 & 28,00 \\
\hline & Total & 10 & & \\
\hline \multirow[t]{3}{*}{ Tugas6 } & Pemula & 5 & 6,40 & 32,00 \\
\hline & Mahir & 5 & 4,60 & 23,00 \\
\hline & Total & 10 & & \\
\hline \multirow[t]{3}{*}{ Tugas7 } & Pemula & 5 & 7,20 & 36,00 \\
\hline & Mahir & 5 & 3,80 & 19,00 \\
\hline & Total & 10 & & \\
\hline \multirow[t]{3}{*}{ Tugas8 } & Pemula & 5 & 8,00 & 40,00 \\
\hline & Mahir & 5 & 3,00 & 15,00 \\
\hline & Total & 10 & & \\
\hline \multirow[t]{3}{*}{ Tugas9 } & Pemula & 5 & 5,70 & 28,50 \\
\hline & Mahir & 5 & 5,30 & 26,50 \\
\hline & Total & 10 & & \\
\hline \multirow[t]{3}{*}{ Tugas 10} & Pemula & 5 & 7,30 & 36,50 \\
\hline & Mahir & 5 & 3,70 & 18,50 \\
\hline & Total & 10 & & \\
\hline \multirow[t]{3}{*}{ Tugas11 } & Pemula & 5 & 5,10 & 25,50 \\
\hline & Mahir & 5 & 5,90 & 29,50 \\
\hline & Total & 10 & & \\
\hline \multirow[t]{3}{*}{ Tugas 12} & Pemula & 5 & 6,60 & 33,00 \\
\hline & Mahir & 5 & 4,40 & 22,00 \\
\hline & Total & 10 & & \\
\hline
\end{tabular}

Dari hasil Tabel 11 yang disajikan pada pengolahan data, diketahui mean rank untuk pengerjaan tugas 1 , tugas 4 , tugas 6 , tugas 7 , tugas 8 , tugas 9, tugas 10 dan tugas 12 pada responden mahasiswa kelompok mahir lebih kecil dari kelompok pemula. Dari data diketahui bahwa waktu pengerjaan tugas 1 , tugas 4 , tugas 6 , tugas 7 , tugas 8 , tugas 9 , tugas 10, dan tugas 12 pada responden mahasiswa kelompok mahir lebih cepat dari responden pemula. Berikut merupakan output test dari hasil pengujian statistic dengan Mann Whitney U-test oleh responden mahasiswa. 
P-ISSN 2252-9063

Kumpulan Artikel Mahasiswa Pendidikan Teknik Informatika

(KARMAPATI)

Volume 8, Nomor 2, Tahun 2019

Tabel 12 Output Test StatistikPengolahan Data Responden Mahasiswa

Test Statistics ${ }^{\mathrm{a}}$

\begin{tabular}{|c|c|c|c|c|c|c|c|c|c|c|c|c|}
\hline & Tugas1 & Tugas2 & Tugas3 & Tugas4 & Tugas5 & Tugas6 & Tugas7 & Tugas8 & Tugas9 & Tugas10 & Tugas11 & Tugas 12 \\
\hline $\begin{array}{l}\text { Mann- } \\
\text { Whitney U }\end{array}$ & 8,000 & 6,000 & 7,000 & 1,000 & 12,000 & 8,000 & 4,000 & ,000 & 11,500 & 3,500 & 10,500 & 7,000 \\
\hline Wilcoxon W & 23,000 & 21,000 & 22,000 & 16,000 & 27,000 & 23,000 & 19,000 & 15,000 & 26,500 & 18,500 & 25,500 & 22,000 \\
\hline Z &,- 946 & $-1,392$ & $-1,156$ & $-2,440$ &,- 105 &,- 943 & $-1,844$ & $-2,785$ &,- 210 & $-1,915$ &,- 419 & $-1,167$ \\
\hline $\begin{array}{l}\text { Asymp. Sig. } \\
\text { (2-tailed) }\end{array}$ &, 344 & 164 & 248 & ,015 & ,917 & ,346 &, 065 & ,005 & ,834 & 055 & 675 & ,243 \\
\hline $\begin{array}{l}\text { Exact Sig. } \\
\text { [2*(1-tailed } \\
\text { Sig.)] }\end{array}$ &, $421^{\mathrm{b}}$ &, $222^{b}$ &, $310^{\mathrm{b}}$ &, $016^{\mathrm{b}}$ & $1,000^{\mathrm{b}}$ &, $421^{\mathrm{b}}$ &, $095^{\mathrm{b}}$ &, $008^{\mathrm{b}}$ &, $841^{\mathrm{b}}$ &, $056^{\mathrm{b}}$ &, $690^{\mathrm{b}}$ &, $310^{\mathrm{b}}$ \\
\hline
\end{tabular}

a. Grouping Variable: Kelompok

b. Not corrected for ties.

Dapat dilihat bahwa nilai p-value 0.344 untuk tugas 1 , 0.164 untuk tugas 2, 0.248 untuk tugas 3, 0.015 untuk tugas 4, 0.917 untuk tugas 5, 0.346 untuk tugas $6,0.065$ untuk tugas 7 , 0.005 untuk tugas $8,0.834$ untuk tugas $9,0.055$ untuk tugas $10,0.675$ untuk tugas $11,0.243$ untuk tugas 12 . Untuk membuat kesimpulan pengolahan data ini, setiap p-value masing-masing perbandingan pada setiap tugas dibandingkan dengan nilai $\alpha$ yang bernilai 0.05 . Apabila nilai $p$-valuenya lebih besar dari 0.05 maka keputusan yang diambil adalah tidak menolak H0. Maka dapat ditarik kesimpulan bahwa secara statistic terdapat perbedaan pada tugas 4 dan tugas 8 , selain itu seluruh tugas dapat dinyatakan tidak ada perbedaan yang signifikan meskipun waktu pengerjaan pada responden mahasiswa mahir sedikit lebih cepat dari responden pemula yang berarti Sistem Informasi PPL Undiksha dari segi pengguna mahasiswa masih belum efisien.

\section{E. Kepuasan Pengguna}

Data yang diperlukan untuk mengukur kepuasan pengguna adalah dengan kuesioner SUS yang telah diisi oleh 10 responden pengguna SI PPL. Hal yang terlebih dahulu dilakukan adalah menghitung nilai skor untuk masing-masing pernyataan dari tiap responden.

Tabel 13 Hasil Kuesioner SUS

\begin{tabular}{|l|r|l|l|l|l|l|l|l|l|r|r|}
\hline \multirow{2}{*}{$\begin{array}{c}\text { Kode } \\
\text { Respon } \\
\text { den }\end{array}$} & \multicolumn{10}{|c|}{ Skor Pernyataan } & \multirow{2}{*}{} \\
\cline { 2 - 12 } & 1 & 2 & 3 & 4 & 5 & 6 & 7 & 8 & 9 & 0 & $\begin{array}{c}\text { Skor } \\
\text { total }\end{array}$ \\
\hline RP1 & 4 & 2 & 4 & 4 & 4 & 4 & 4 & 2 & 4 & 4 & 36 \\
\hline RP2 & 4 & 3 & 5 & 1 & 4 & 2 & 4 & 1 & 4 & 2 & 30 \\
\hline RP3 & 4 & 4 & 4 & 2 & 4 & 2 & 4 & 2 & 4 & 4 & 34 \\
\hline RP4 & 4 & 3 & 3 & 2 & 3 & 2 & 3 & 3 & 3 & 4 & 30 \\
\hline RP5 & 5 & 2 & 4 & 2 & 4 & 2 & 4 & 2 & 4 & 2 & 31 \\
\hline RM1 & 4 & 3 & 4 & 3 & 5 & 3 & 4 & 3 & 4 & 4 & 37 \\
\hline RM2 & 5 & 3 & 5 & 2 & 5 & 2 & 5 & 2 & 5 & 3 & 37 \\
\hline
\end{tabular}

\begin{tabular}{|c|c|c|c|c|c|c|c|c|c|c|c|}
\hline \multirow{3}{*}{$\begin{array}{c}\text { Kode } \\
\text { Respon } \\
\text { den }\end{array}$} & \multicolumn{10}{|c|}{ Skor Pernyataan } & \multirow{3}{*}{$\begin{array}{l}\text { Skor } \\
\text { total }\end{array}$} \\
\hline & $\mathrm{P}$ & $P$ & $\mathrm{P}$ & $\mathrm{P}$ & $\mathrm{P}$ & $\mathrm{P}$ & $\mathrm{P}$ & $\mathrm{P}$ & $\mathrm{P}$ & P1 & \\
\hline & 1 & 2 & 3 & 4 & 5 & 6 & 7 & 8 & 9 & 0 & \\
\hline RM3 & 4 & 4 & 5 & 2 & 4 & 3 & 5 & 2 & 4 & 3 & 36 \\
\hline RM4 & 5 & 2 & 4 & 2 & 4 & 2 & 4 & 2 & 4 & 4 & 33 \\
\hline RM5 & 5 & 5 & 5 & 2 & 3 & 2 & 5 & 2 & 5 & 2 & 36 \\
\hline Total & \multicolumn{11}{|c|}{340} \\
\hline $\begin{array}{l}\text { Rata- } \\
\text { rata }\end{array}$ & \multicolumn{11}{|c|}{68} \\
\hline
\end{tabular}

Perolehan nilai skor untuk kuesioner responden mahasiswa adalah sebesar 68. Hal ini berarti nilai skor tersebut lebih kecil dari skor standar SUS yaitu 70. Sehingga dapat dikatakan bahwa responden mahasiswa belum puas menggunakan Sistem Informasi PPL Undiksha.

F. Rekomendasi Perbaikan

Sistem Informasi PPL Undiksha memiliki nilai keefektifan 96,3\% yang termasuk dalam kategori efektif dan hasil efisiensi masih membutuhkan perbaikan berdasarkan masukan responden yang diperoleh dari teknik restropective think aloud (RTA). Berdasarkan Tabel tersebut dapat disimpulkan secara umum bahwa masih terdapat kendala sewaktu menggunakan Sistem Informasi PPL. Beberapa diantara kendalanya yaitu terlalu kecil fitur Lihat Pengumuman yang susah dilihat oleh pengguna, dan tidak terdapat fitur Hapus file pada menu Upload File.

Rekomendasi yang diberikan berupa rancangan/ wireframe menggunakan aplikasi mock up, yang mengacu pada teori perancangan. Teori tersebut yaitu eight golden rules oleh Benn Shneiderman. Berikut pembahasan delapan aturan emas pada layanan Sistem Informasi PPL. 
1. Rekomendasi Perbaikan Lihat Pengumuman

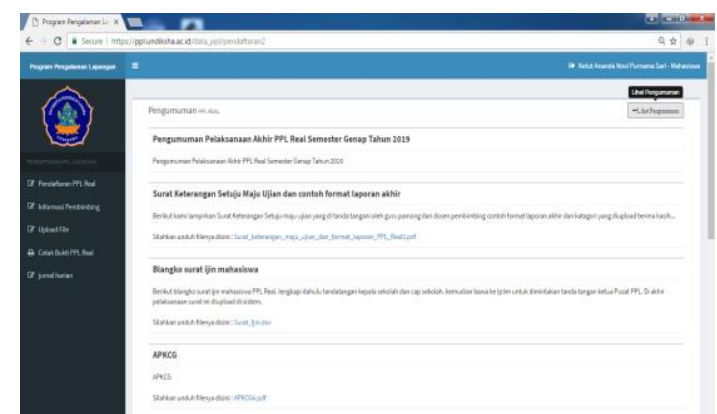

Gambar 3 Tampilan Fitur Lihat Pengumuman Sebelum Perbaikan

Fitur Lihat Pengumuman pada Sistem Informasi PPL melanggar aturan 8 golden rules yaitu Reduce short-term memory load, yaitu ketika pengguna berada pada halaman Pendaftaran PPL Real, hal yang dirasakan adalah kebingungan karena tampilan yang terlihat adalah data diri mahasiswa dan disaat ingin melihat pengumuman pengguna masih maerasa kebingungan karena letak fitur Lihat Pengumuman berada di pojok kanan atas yang dimana ukuran terlalu kecil untuk dilihat, sehingga pengguna bingung untuk mencari tombol Lihat Pengumuman

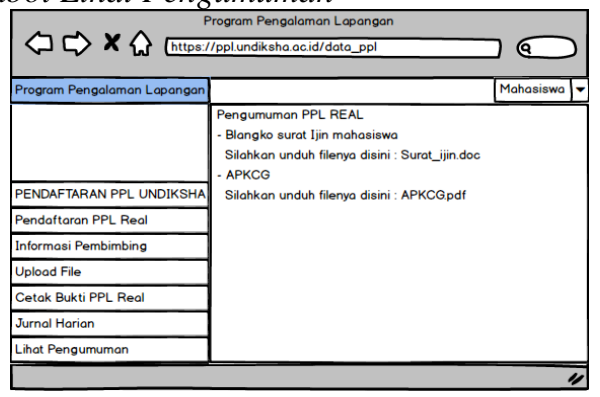

Gambar 4 Tampilan Fitur Lihat Pengumuman Setelah Perbaikan

Perbaikan ini dilakukan pada tata letak fitur Lihat Pengumuman. Perbaikan yang dilakukan adalah terfokus pada penyesuaian tata letak tombol Lihat Pengumuman yang semula berada di bagian atas kanan lalu sekarang menjadi di bagian kiri. Tombol dipindahkan karena pengguna sering merasa kebingungan dan membutuhkan waktu lama untuk mencari fitur lihat pengumuman. Maka dari itu dibuatkan letak fitur lihat pengumuman pada bilah kiri yang sejajar dengan menu yang lainnya agar mencegah pengguna merasa kebingungan saat menjalankan sistem.

\section{Rekomendasi Perbaikan Menu Upload File}

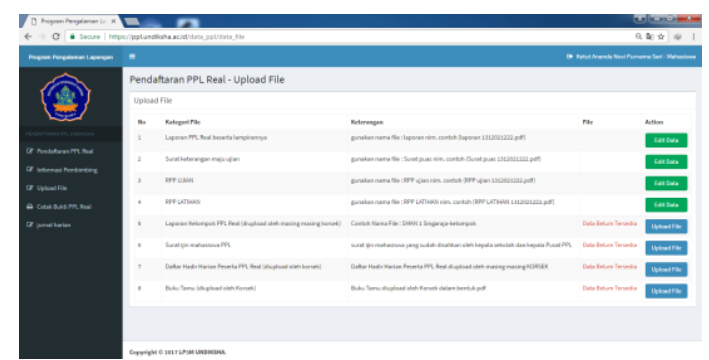

Gambar 5 Tampilan Menu Upload File Sebelum Perbaikan
Menu Upload File pada Sistem Informasi PPL melanggar aturan 8 golden rules yaitu Reduce short-term memory load, yaitu pada halaman Upload File, hal pertama yang dirasakan pengguna saat melakukan kesalahan upload file dan ingin menghapus data yang telah tersave adalah kebingungan karena tidak tersedianya fitur Hapus File.

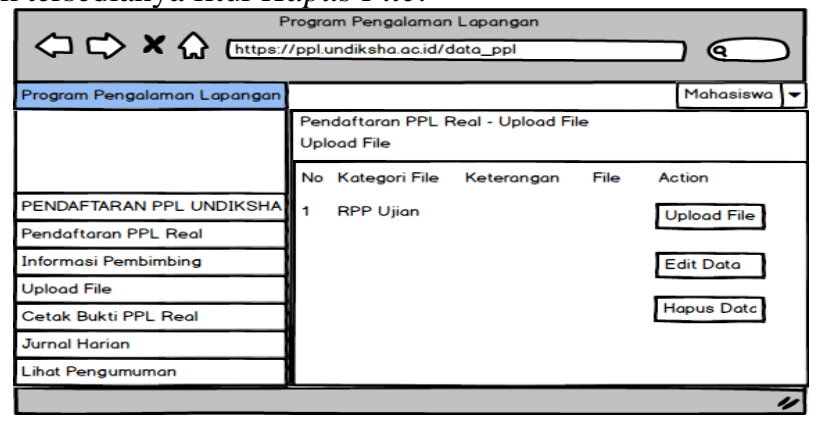

Gambar 6 Tampilan Menu Upload File Setelah Perbaikan

Perbaikan ini dilakukan pada menu Upload File. Perbaikan yang dilakukan adalah terfokus pada penambahan tombol Hapus Data yang semula hanya terdapat tombol Upload File dan tombol Edit saja. Penambahan tombol tersebut difungsikan untuk mencegah pengguna merasa kebingungan saat menghapus file yang ketika pengguna salah mengupload file atau berkas.

\section{SIMPULAN}

Berdasarkan hasil penelitian yang dilakukan tentang evaluasi usability pada Sistem Informasi PPL Undiksha dengan metode usability testing dapat disimpulkan sebagai berikut.

\section{Efektivitas}

Dari hasil yang didapat dengan Teknik performance measurement menunjukkan halaman Sistem Informasi PPL Undiksha secara umum efektif karena Rata-rata minimum penyelesaian tugas pada pengujian usability adalah $78 \%$, sehingga hasil ratarata keefektifitasan Sistem Informasi PPL yang menghasilkan $96,3 \%$ tersebut termasuk dalam kategori efektif.

2. Efisiensi

Jika dilihat dari hasil data yang didapat dengan Teknik performance measurement diketahui bahwa responden mahasiswa secara statistic terdapat perbedaan pada tugas 4 dan tugas 8 , selain itu seluruh tugas dapat dinyatakan tidak ada perbedaan yang signifikan meskipun waktu pengerjaan pada responden mahasiswa mahir sedikit lebih cepat dari responden pemula yang berarti Sistem Informasi PPL Undiksha dari segi pengguna mahasiswa masih belum efisien.

3. Kepuasan Pengguna

Perolehan nilai skor untuk kuesioner responden mahasiswa adalah sebesar 68 . Hal ini berarti nilai skor tersebut lebih kecil dari skor standar SUS yaitu 70. Sehingga dapat dikatakan bahwa responden 
mahasiswa belum puas menggunakan Sistem Informasi PPL Undiksha.

4. Hasil yang didapat dari proses usability testing diketahui bahwa halaman Sistem Informasi PPL Undiksha yang menjadi objek penelitian belum memenuhi kriteria sebuah produk dengan usability yang baik. Hal ini dapat dilihat pada penilaian tingkat efektivitas, efisiensi, dan kepuasan pengguna, jadi halaman Sistem Informasi PPL Undiksha ini belum mampu memenuhi kriteria yang baik untuk kedua aspek tersebut.

5. Rekomendasi perbaikan dalam penelitian ini difokuskan untuk mengubah tata letak (layout) halaman dan menu navigasi pada hasil data penyebab kesalahan (error) pada pengguna. Perbaikan digunakan dengan membuat wireframe halaman Sistem Informasi PPL Undiksha.

\section{REFERENSI}

[1] Arifin, M. (2014). Analisa Dan Perancangan Sistem Informasi Praktek Kerja Lapangan Pada Instansi/Perusahaan. Simetris: Jurnal Teknik Mesin, Elektro Dan Ilmu Komputer, 5(1), 49-56. Https://Doi.Org/10.1002/Jcb.22035.T-Box

[2] Fitria, N., \& Fidesrinur. (2017). Praktik Pengalaman Lapangan, 4(1), 41-52.

[3] Prayoga, S. H., \& Sensuse, D. I. (2013). Analisis Usability Pada Aplikasi Berbasis Web Dengan Mengadopsi Model Kepuasan Pengguna (User Satisfaction), 6, 64-73.

[4] W, M. A. D., W, E. A., Ramadhan, D. W., \& Saputra, M. A. (2015). Evaluasi Usability Untuk Mengukur Penggunaan Website Event Organizer. Seminar Nasional Informatika 2015, 428-434.

[5] Utama, S. (2011). Perbaikan User Interface Halaman Internet Banking Dengan Metode Usability Testing.

[6] Yasin, A., \& Mz, Y. (2016). Evaluasi Web Ujb Menggunakan Golden Rules Of User Interface Designtheo Mandel, (February).

[7] Henriyadi, \& Mulyati, R. (2014). Usability Testing Sistem Informasi: Studi Kasus Padaaplikasi Repositori Publikasi Badan Penelitian Dan Pengembangan Pertanian, (Agustus).

Https://Doi.Org/10.21082/Jpp.V23n2.2014.P54-63

[8] Santosa, A. P. (2010). Hubungan Pengajaran Mikro Dan Program Pengalaman Lapangan Ii Di Sekolah Dengan Minat Mahasiswa Fkip Menjadi Guru.

[9] Shneiderman, B., \& Plaisant, C. (2000). Designing The User Interface: Strategies For Effective HumanComputer Interaction. Zeitschrift Für Papyrologie Und
Epigraphik (Vol. 131).

[10] Krug, S. (2006). Don't Make Me Think.

[11] Pudjoatmodjo, B., \& Wijaya, R. (2016). Tes Kegunaan (Usabilty Testing) Pada Aplikasi Kepegawaian Dengan Menggunakan System Usabilty Scale (Studi Kasus: Dinas Pertanian Kabupaten Bandung), 6-7. 